ANNA REIWER-KALISZEWSKA ${ }^{1}$, TOMASZ D. NOWAK ${ }^{2}$

\title{
Customs and Tax Inspection in Trading between the European Union and Third Party Countries
}

\begin{abstract}
As a result of a reform implemented in 2017, the National Revenue Administration ${ }^{3}$ was established in place of the existing tax administration, tax inspection, and the Customs Service. The tax administration was consolidated this way. Although the efficiency of collecting VAT, excise tax and fuel duty increased, there are still areas which require an analysis of the definition, statistical and legal scope, and an increase in the efficiency of enforcing compliance with both the European Union's regulations on customs and tax and the Polish ones. The purpose of this paper is to analyse the functioning of regulations which have been applicable since 1 March 2017 and which concern customs and tax inspection of the assessment and collection of charges, which are related the import and export of goods onto the customs territory of the European Union, by the new authorities.
\end{abstract}

Keywords: National Revenue Administration, customs and tax inspection, excise tax, fuel duty, VAT

Anna Reiwer-Kaliszewska - University of Business and Administration in Gdynia; e-mail areiwer@ yahoo.co.uk; ORCID: 0000-0002-6724-8137.

2 Tomasz D. Nowak - Tax and Customs Office in Opole; e-mail tomasz.nowak3@mf.gov.pl; ORCID: 0000-0001-6022-9139.

3 In Polish: Krajowa Administracja Skarbowa [translator's note]. 


\section{Introduction}

Before 1 March 2017, the assessment and collection of customs duties and other fees related to the import and export of goods, as well the assessment and collection of tax on goods and services and excise tax and fuel duty was the responsibility of the Customs Service ${ }^{4}$. These were "traditional" and, from the point of view of national economic interests, the most essential areas of its activity. The extension of the powers of the Customs Service by the assessment and collection of the tax on goods and services on the import of goods, and control, special tax supervision, as well as the assessment and collection of the excise tax, followed by the fuel duty, were attributed to customs offices only as of 1 September 2003. Before that day, the collection of those levies were the competence of the heads of tax offices ${ }^{5}$. The purpose of this change was to make, on the eve of the entry into the EU, the organisation and competence of the tax administration closer to the standards used in the countries of the European Union ${ }^{6}$. This solution, actually dominating in the member states, is a consequence of the construction of this tax, based on the regulations of the customs law ${ }^{7}$.

The realisation of the above-mentioned tasks was served especially by control activities performed by the heads of customs offices and the directors of customs chambers - depending on the subject of an inspection - on the basis of provisions

4 The provisions of the Union's custom's law allow the establishment of so-called export duties. Such duties have not been established by the EU so far.

5 Article 34a of the Act of 8 January 1993 on the Tax on Goods and Services and on the Excise Tax, regulating the competence of authorities in excise tax was added to the Act on the basis of Article 11 point 21 of the Act of 27 June 2003 on Establishing Voivodship Tax Collegiums and on Amending Certain Acts Regulating the Tasks and Competences of Authorities and the Organisation of Organisational Units Subject to the Minister in Charge of Public Finance (Dz. U. z 2003 r. Nr 137, poz. $1302 \mathrm{ze}$ zm. / Journal of Laws of 2003 No. 137, item 1302 as amended).

6 See Explanatory statement to the draft Act of 27 June 2003 on Establishing Voivodship Tax Collegiums and on Amending Certain Acts, source: http://orka.sejm.gov.pl/Druki4ka.nsf/(\$vAllByUnid)/248EE1CC2E96266CC1256C54002629C0/\$file/991_01.pdf, 9 October 2018.

7 See K. Piech, Procedura tranzytu jako pierwowzór procedury zawieszenia poboru akcyzy. O zwiazkach prawa akcyzowego z prawem celnym na podstawie doświadczeń niektórych państw członkowskich Unii Europejskiej, in: Prawo celne i podatek akcyzowy. Kierunki przeobrażeń i zmian, eds. P. Stanisławiszyn, T. Nowak, Warsaw 2014, p. 360-381. 
of the Act on the Customs Service ${ }^{8}$ (in the case of import or export) or according to the rules specified in Part VI of the Tax Ordinance Act ${ }^{9}$ (with reference to the excise tax and the fuel duty in domestic trading and trading between the EU member states) ${ }^{10}$. Inspection concerning customs duties and other fees related to the import and export of goods, and taxes on the import and export of goods, as well as the excise tax and the fuel duty was also carried out by the director of a treasury control office on the basis of the Act of 28 September 1991 on Fiscal Control ${ }^{11}$.

The rules of controlling the import of goods onto the customs territory of the European Union and export from that territory (until 1 May 2004, this concerned the customs territory of the Republic of Poland), as well as controlling goods subject to quantitative quotas, the excise tax and the fuel duty, were thus regulated by three separate acts, used by the heads of customs offices and the directors of customs chambers, as well as the heads of treasury control offices, who acted independently, but co-operated with one another.

On 1 March 2017, the Act on the National Revenue Administration ${ }^{12}$ (hereinafter referred to as: the NRA Act) came into force. The Act on the Customs Service and the Act on Fiscal Control were repealed ${ }^{13}$. In their place, the heads of tax and customs offices and the directors of tax administration chambers were appointed. Pursuant to Article 2 section 1 point 1 and 2 of the NRA Act, the fundamental tasks of the NRA include the realisation of income from taxes, fees and non-tax budget receivables, as well as other receivables, on the basis of separate provisions, with the exception of taxes and budget receivables which different authorities are in charge of, and the realisation of income from customs duties and other fees related to the import and export of goods.

It also seems from the preamble to the NRA Act that adopting this act, the legislator was guided by the financial security of the Republic of Poland and, at

8 See Article 2 section 1 point 2, section 2, section 4 of the Act of 27 August 2009 on the Customs Service (tekst jedn. Dz. U. z 2016 r., poz. 1799 ze zm. / consolidated text Journal of Laws of 2016, item 1799 as amended).

9 In Polish: Ordynacja podatkowa [translator's note].

10 Act of 29 August 1997 - the Tax Ordinance Act (tekst jedn. Dz. U. z 2018 r., poz. 800 ze zm./consolidated text Journal of Laws of 2018, item 800 as amended, hereinafter referred to as the T.O.A.).

11 See Article 2 section 1 point 1 and 12 of the Act of 28 September 1991 on Fiscal Control (tekst jedn. Dz. U. z 2016 r., poz. 720 ze zm. / consolidated text Journal of Laws of 2016, item 720 amended).

12 Consolidated text: Dz. U z 2018 r., poz. 508 ze zm. / Consolidated text Journal of Laws of 2018, item 508 as amended, hereinafter referred to as the NRA Act.

13 See Article 159 and Article 160 of the Act of 16 November 2016 - Provisions introducing the Act on the National Revenue Administration (Dz. U. poz. 1948 ze zm./Journal of Laws, item 1948 as amended). 
the same time, bore in mind the protection of the safety of the European Union's customs territory.

Such significant changes in the activity of authorities responsible for national financial security justify the evaluation of their functioning in the light of over two-year experiences. Due to the adopted framework of the publication, the authors focus their analysis on the functioning of the regulations applicable since 1 March 2017 for the new authorities' assessment and collection of charges related to the import and export of goods onto the customs territory of the European Union. In the light of the anticipated exit of Great Britain from the European Union and a probable increase in the number of submitted customs applications in connection with that exit, this topic, regardless of the writers' intentions, will become an issue concerning a much larger circle of entities than ever before.

\section{The Union Customs Code and regulations concerning the customs territory of the EU and the mission of customs authorities}

The customs territory of the European Union should be understood as territories, including their territorial waters, internal waters and airspace, enumerated in Article 4 of the Union Customs Code ${ }^{14}$ (hereinafter referred to as the UCC). The exclusions of territories which are not part of the Union customs territory were also included there. It should be emphasised that the territories of individual member states are not identical to the customs territory of the European Union. Similarly, territories which are not part of individual member states may belong to the customs territory of the European Union. In the case of the Republic of Poland, its entire territory has been part of the Union customs territory since 1 May 2004.

The mission of customs authorities was specified in Article 3 of the UCC, pursuant to which these authorities are responsible for the supervision of the Union's international trade, thereby contributing to fair and open trade, to the implementation of the external aspects of the internal market, of the common trade policy and of the other common Union policies having a bearing on trade, and to overall supply chain security. The customs authorities have competences to introduce measures aimed, in particular, at the following:

14 Regulation (EU) No 952/2013 of the European Parliament and of the Council of 9 October 2013 laying down the Union Customs Code (recast), Official Journal of the EU L.2013.269.1. 
a) protecting the financial interests of the Union and its Member States;

b) protecting the Union from unfair and illegal trade while supporting legitimate business activity;

c) ensuring the security and safety of the Union and its residents, and the protection of the environment, where appropriate in close cooperation with other authorities; and

d) maintaining a proper balance between customs controls and facilitation of legitimate trade, i.a. within the framework of quantitative quotas.

\section{The definition and scope of customs and tax inspection}

There is no legal definition of customs and tax inspection in the Act on the National Revenue Administration. An accurate definition of it was proposed by A. Melezini ${ }^{15}$ in whose opinion, a customs and tax inspection constitutes "a specific type of administrative procedure of a police nature"16. This is a string of activities regulated by the provisions of the Act, and these activities are undertaken by the participants of the procedure. The said procedure is initiated with the authorisation of a tax and customs authority, and it ends with the issuance of a decision in the form of an inspection result or a report from a given inspection by that authority ${ }^{17}$.

The subject matter of customs and tax inspection is very broad. It was based on provisions included in the Act on Fiscal Control and the Act on the Customs Service, which were applicable before 1 March 2017. Pursuant to Article 54 section 1 of the NRA Act, customs and tax inspection covers, among other things, compliance with the provisions of the tax law within the meaning of Article 3 point 2 of the Tax Ordinance Act (that is, the provisions of tax acts, the resolutions of double taxation conventions ratified by the Republic of Poland, and other international agreements concerning the tax issue, which were ratified by the Republic of Poland, as well as the provisions of executive acts issued on the basis of tax acts), compliance with the provisions of the customs law and other provisions related to the import and export of goods in trade between the customs territory of the European Union and third party states, as well as compliance with provisions regulating the organisation and holding of gambling games, the provisions of the foreign exchange law, and the provisions on prevention of money-laundering and financing terrorism.

15 A. Melezini, in: Krajowa Administracja Skarbowa. Komentarz, eds. A. Melezini, K. Teszner, Wolters Kluwer, Warsaw 2018, p. 235.

16 Own translation [translator's note].

17 A. Melezini, op. cit., p. 235. 
An essential issue of quantitative control in the customs law is the necessity of enforcing by the NRA an actual amount of fuel which is imported to Poland from third party states, mostly from the east, in standard petrol tanks in cars. Instead of a one-time amount of 200 litres, which is tax-exempt on the basis of the Act on the Excise Tax, the authorities detect numerous cases of transporting over 600 litres, which requires an urgent finalisation of the work on the draft amendment to the Act of 19 March 2004 - the Customs Law (Dz. U. z 2004 r. poz. 622 / Journal of Laws of 2004 item 622) ${ }^{18}$. The above-mentioned loophole currently provides too many possibilities of importing fuels illegally, the sale of which generates revenue for the grey market.

The subject matter of customs and tax inspection covers all legal persons, natural persons, organisational units without legal personality, obligated to comply with the law in the scope mentioned above. Thus, the circle of controlled entities was determined by the type of business conducted and the necessity related thereto of complying with the provisions of applicable law ${ }^{19}$. An example of such control is the use of criminal penalties for licenced entities within the framework of the realisation of the National Index Target and the provisions of the backup act ${ }^{20}$. Analysts from $\mathrm{PwC}$ postulate that for natural persons who performed managerial duties in entities which did not discharge the NIT, it should be more difficult to obtain a licence in their subsequent economic entities selling fuels ${ }^{21}$. An additional postulate is to tighten the process of issuing new licences as much as possible, considering the above-mentioned infringements of the NIT as reasons for a refusal to grant a licence. According to $\mathrm{PwC}_{\mathrm{w}}$, a customs and tax inspection carried out by the NRA and police units should be frequent, complex, and, first of all, effective. A subjective inspection should be focused asymmetrically, according to the highest risk factors. The NRA should control new economic entities or those which have been functioning on the excise products market for a short time.

A customs and tax inspection is conducted by the heads of tax and customs offices. This is based on the provisions of Part V of the NRA Act, and within the

18 Report by PwC, Walka z szara strefa. Wptyw regulacji na branżę paliw ptynnych, p. 25, http://ungc.org. $\mathrm{pl} /$ strefa-wiedzy/22202/, 31 January 2019.

19 A. Nadolska, Administracja skarbowa, In: Podstawy prawa finansowego, ed. A. Drwiłło, Wolters Kluwer, Warsaw 2018, p. 255.

20 Act of 16 February 2007 on Reserves of Petroleum, Petroleum Products and Natural Gas and on the Code of Conduct in the Event of Threat to National Petroleum Security and Petroleum Market Disturbances. In Polish: Ustawa z dnia 16 lutego 2007 r. o zapasach ropy naftowej, produktów naftowych i gazu ziemnego oraz zasadach postępowania w sytuacjach zagrożenia bezpieczeństwa paliwowego państwa i zakłóceń na rynku naftowym.

$21 \quad$ PwC, op. cit., p. 57. 
unregulated scope, pursuant to Article 94 of the NRA Act, the provisions of the Tax Ordinance Act are applied to a customs and tax inspection, respectively, though excluding the directly indicated regulations. Moreover, the provisions of the Act of 6 March 2018 - the Law of Entrepreneurs also do not apply to the customs and tax inspection ${ }^{22}$. The above means that the institution of a notification about an intended inspection, as well as limitations on the duration of that inspection, which were indicated in this act, will not apply in the customs and tax inspection procedure.

The NRA Act does not use the term "customs inspection" that functions on the grounds of the Union's customs law and the national one ${ }^{23}$. Nevertheless, its use in the case of a customs and tax inspection in connection with following the provisions of the customs law should not be considered a mistake. The Union customs law is applied directly and uniformly in all member states, and the national customs law is only subsidiary in relation to the Union's regulations. Simultaneously, it should be noted that a "customs inspection", or a customs and tax inspection regarding compliance with the provisions of the customs law does not cover taxes accompanying customs duties. This is about VAT, the excise tax and the fuel duty ${ }^{24}$, collected in connection with the import of goods. This is because the concept of a customs inspection concerns the provisions of the customs law, while the enumerated levies collected in connection with import are not customs duties. Therefore, the concept of the customs and tax inspection of goods trading with countries outside the European Union, as used by the authors, will also concerns tax liabilities on import, and in some cases, the fuel duty as well. Thus, considering that using the term "customs inspection" is permissible in the case of control activities regarding trading with third party countries, one should remember the scope of its

22 See Article 93 of the NRA Act. The Act of 6 March 2018 - the Law of Entrepreneurs (Dz. U. poz. 646 ze zm. / Journal of Laws item 646 as amended) came into force on 30 April 2018, replacing the Act of 2 July 2004 on Freedom of Business Activity (tekst jedn. Dz. U. z 2017 r. poz. 2168 ze zm. / consolidated text Journal of Laws of 2017 item 2168 as amended).

23 See Article 5 section 3, Article 46-48 of the UCC. The Polish Act of 19 March $2004-$ the Customs Law (tekst jedn. Dz. U. z 2018 r., poz. 176 ze zm. / consolidated text Journal of Laws of 2018, item 176 as amended) uses the term "customs inspection" several times (Article 17, Article 20, Article 61, Article 71, Article 96 of the Act).

24 The fuel duty, the assessment and collection of which were specified in the Act of 27 October 1994 on Toll Motorways and the National Road Fund (tekst jedn. Dz.U. z 2018 r., poz. 2014 ze zm. / consolidated text Journal of Laws of 2018, item 2014 as amended), is the revenue of the National Road Fund and the Railway Fund. Despite the fact that this duty is not a tax, it has the features of a tax (see K. Lasiński-Sulecki, Opłata paliwowa - próba oceny zgodności z prawem Unii Europejskiej, in: Prawo celne i podatek akcyzowy..., pp. 124-137. For the legislator's specification of authorities in charge of the fuel duty, see A. Reiwer-Kaliszewska, T. Nowak, Właściwość organów Krajowej Administracji Skarbowej w postępowaniu z tytułu importu towarów oraz w sprawach opłaty paliwowej In: Prawo celne, podatek akcyzowy oraz kary pieniężne w ustawie o grach hazardowych. Doświadczenia i wyzwania, eds. T. Nowak, P. Stanisławiszyn, Szczecin 2018 pp. 241-257. 
meaning. The issue of the proper collection of the excise tax, and defining the scope of its application has become of importance since the fuel package came into force in August 2016. According to the analysts from PwC, the increase in the collection of VAT by $18 \%$ was accompanied by only a $5.3 \%$ increase in the collection of the excise $\operatorname{tax}^{25}$. It should be presumed that the definitions of the types of fuels produced in refineries, and of imported fuels which are ready for use cause an artificial diversity of statistical codes, which makes it easier to declare production or import which is beyond the scope of the excise tax collection. Importers may declare the import of such oils which are not classified as fuel oils. PwC also notices a reversal in the existing formula of importing fuels. Before the introduction of the fuel package, the excise tax was declared, but VAT was not, and after the package was introduced, VAT was declared, but the excise tax was not. Therefore, it seems necessary that the professionalism level of the statistical service, the NRA as well as the Central Investigation Bureau of Police (CBŚP) ${ }^{26}$ be increased in order to increase physical inspections so that this practice would be limited.

The initiation of a customs and tax inspection occurs ex officio, on the basis of an authorisation to conduct a customs and tax inspection granted to the controller, whereas the initiation date is the day when that authorisation is delivered to the controlled entity. In 14 days from the day of the delivery of the authorisation to conduct a customs and tax inspection, the controlled entity has the right to correct its declaration within the scope covered by the inspection. The correction of the declaration which is submitted after that deadline and before the end of the customs and tax inspection has no legal effect ${ }^{27}$.

Apart from inspections realised on the basis of an authorisation delivered to the controlled party, the NRA authorities also conduct inspections on the basis of a presented identity folder and a permanent authorisation to conduct such inspections. This concerns i.a. controls on public or internal roads, in seaports and harbours, on internal seawaters, at territorial sea, in a contiguous zone or on inland waters $^{28}$. In urgent situations, the initiation of an inspection on the basis of a presented identity folder is also possible (a so-called "legitimised" inspection) ${ }^{29}$.

In Article 63 section 1 of the NRA Act, a principle which consists in the fact that a customs and tax inspection should be finalised without further ado, but not

\footnotetext{
$25 \quad$ PwC, op. cit., p. 45.

26 In Polish: Centralne Biuro Śledcze Policji [translator's note].

27 See Article 62 section 1, 2 and 4 of the NRA Act.

28 The terms referred to are discussed by T. Nowak in: Krajowa Administracja Skarbowa. Komentarz, eds. A. Melezini, K. Teszner, Wolters Kluwer, Warsaw 2018, pp. 284-585.

29 See Article 62 section 3 and 5 of the NRA Act.
} 
later than 3 months after the day of its initiation, was provided for. The controlled party is to be notified in writing of every case of non-discharge of the customs and tax inspection within an appropriate time, giving reasons for the extension of the deadline for completing the customs and tax inspection and indicating a new date for the completion of that inspection. This regulation will undergo a significant modification when its subject is the verification of compliance with the provisions of the customs law, that is, a "customs inspection" within the meaning of this law. Pursuant to Article 63 section 3 of the NRA Act, the three-month deadline for the duration of a customs and tax inspection does not apply when the latter is conducted i.a. on the basis of directly applied provisions of the EU law. Therefore, a customs and tax inspection regarding compliance with the provisions of the customs law - within the meaning of the provisions of the customs law, it is a "customs inspection" - will not be subject to limitations as to its duration, which result from the NRA Act. Such limitations are also not included in the Union customs law or in the national one. Obviously, the duration of an inspection will be determined by the principle of procedural economy and the limitation period.

Determining the duration of a customs and tax inspection may cause some practical difficulty when the inspection covers both customs duties and tax liabilities in import (excluding VAT, it may also be about the excise tax or the excise tax and fuel duty). It seems that in the case of import, a customs and tax inspection should be limited to the control of following the provisions of the customs law. Determining the amount of a tax liability for import (the tax on goods and services, relatively also the excise tax or the excise tax and the fuel duty) is the consequence of establishing the customs value and customs duties. For this reason, the tax liabilities may be specified in a tax proceeding without the necessity of the prior initiation of a customs and tax inspection in this respect.

Obviously, it is still possible to initiate a separate customs and tax inspection regarding import tax liabilities. In the case of a prior establishment of the customs value and customs duties, however, there is no such a necessity if the import tax basis is composed of i.a. the customs value of a product, and the customs duty. It is only in the case of the time-barring of customs duties, if import tax liabilities have not become time-barred yet, when there is a necessity of fixing the tax basis, that the initiation of a customs and tax inspection concerning the import tax liabilities is valid. Then such an inspection will be subject to time limitations discussed in Article 63 of the NRA Act. 


\section{The tasks and powers of the Tax and Customs Service}

The actions of the legislator reforming the functioning of authorities in terms of trading with third party countries had to take the applicable Union customs law into consideration, and this law is superior to the national one. Thus, the changes introduced with the NRA Act in terms of customs inspection are not as significant as in the case of control of tax liabilities, though they are not simply cosmetic changes, either. First of all, within the framework of the National Revenue Administration, the Tax and Customs Service was established. It replaced the existing Customs Service. Nevertheless, the tasks of the new formation regarding compliance with the provisions of the customs law and other provisions related to the export and import of goods in trading between the customs territory of the EU and third party countries remained unchanged, and they cover two basic areas: a financial one, related to the collection and assessment of customs duties and taxes related to the import of goods, and a non-economic one, connected with the control of a number of provisions which have an influence on the EU citizens' health, lives and safety. This is about, among other things, controlling the import of contaminated foods and medicines (infected with e.g. bird flu, mad cow disease), the protection of cultural properties, intellectual property and trademarks (control of the import of so-called counterfeits), as well as endangered protected species of plants and animals ${ }^{30}$. Thus, when it comes to the competence of customs and tax inspection, there is a wide range of regulations, starting from sanitary provisions to regulations concerning security and defence. On the other hand, the formal side of documenting the conducted customs and tax inspection concerning compliance with the provisions of the customs law was changed. The legislator introduced a principle (Article 84 section 1 in connection with Article 54 section 1 point 2 of the NRA Act), pursuant to which a customs and tax inspection in terms of the customs law and other provisions related to the import or export of goods in trading between the customs territory of the EU and third party countries ends with a report. This allows for, depending on the content of the report, making a decision on further action in the matter, e.g. by initiating a customs proceeding. The said report should include particularly the indication of the controlled party and the controller, the determination of the subject and scope of a customs and tax inspection, the

30 I. Sobczyk, Ochrona i bezpieczeństwo obszaru celnego Wspólnoty Europejskiej w zadaniach i kompetencjach Służby Celnej, in: Bezpieczeństwo w administracji i biznesie we współczesnym świecie, eds. M. Chrabkowski, C. Tatarczuk, J. Tomaszewski, University of Business and Administration in Gdynia, Gdynia 2011, pp. 182-183. 
establishment of the place and time of conducting the inspection, a description of factual findings, and documentation regarding the evidence.

However, the manner of proceeding of the head of a tax and customs office conducting a customs and tax inspection as regards the import tax on goods and services (and, potentially, the excise tax or the excise tax and the fuel duty) remains unclear. As indicated above, these are not customs duties. Thus, they are not subject to the control of compliance with the provisions of the customs law, and as such, they should be subject to the control of following the provisions of the tax law. The literal wording of Article 54 section 1 point 1 of the NRA Act thus allows conducting a customs and tax inspection in the scope of import taxes. Additionally, considering the content of Article 61 of the NRA Act, pursuant to which the head of a tax and customs office can conduct customs and tax inspection in the entire Republic of Poland, it may be concluded from the provisions of the NRA Act that the head of the tax and customs office has power to conduct customs and tax inspection regarding import taxes in the entire country.

In the case of the import of goods, the proposed interpretation of the provisions of the NRA Act should, however, be verified by confronting it with the regulations of the Act on the Tax on Goods and Services and the Act on the Excise Tax ${ }^{31}$. Taxable persons are basically obligated to calculate and declare the amount of tax in their customs applications, including the applicable tax rates (Article 33 section 1 of the A.T.G.S. and Article 27 section 1 of the A.E.T.). If an irregularity in relation to the declared VAT amount is revealed before the release of goods, the head of the tax and customs office which accepted the customs application will act ex officio and will issue a decision determining the correct amount of tax (Article 33 section 2 of the A.T.G.S. and Article 27 section 4 of the A.E.T.) or - if the taxable person "reacts" faster - the head of the tax and customs office will issue a decision determining the correct amount of tax upon the taxable person's request.

After the release of goods, the amount of tax due on the import of goods is determined by the head of the tax and customs office by way of a decision (Article 34 of the A.T.G.S. and Article 27 section 6 of the A.E.T.). It is also when, pursuant to the customs legislation, notifying a debtor of the amount of that person's customs debt cannot occur due to the limitation period, and five years have not passed yet, counting from the end of the calendar year in which the tax on the import of goods became chargeable and there is a tax basis to calculate or verify the tax liabilities,

31 See Articles 33-40 of the Act of 11 March 2004 on the Tax on Goods and Services (tekst jedn. Dz. U. z 2018 r., poz. 2174 ze zm. / consolidated text Journal of Laws of 2018, item 2174 as amended, hereinafter referred to as: the A.T.G.S.) and Articles 27-29a of the Act of 6 December 2008 on the Excise Tax (tekst jedn. Dz. U z 2018 r., poz. 1114 ze zm. / consolidated text Journal of Laws of 2018, item 1114 as amended, hereinafter referred to as: the A.E.T.). 
that the head of the tax and customs office may determine the taxation elements according to the rules specified in the customs legislation for the needs of the correct establishment of the amount of tax due on the import of goods (Article 38 section 2 of the A.T.G.S. and Article 29 of the A.E.T.).

The manner of correcting a customs application, indicated on the grounds of the Act on the Tax on Goods and Services and the Act on the Excise Tax thus precludes the possibility of submitting a correction which is discussed in Article 62 section and Article 82 section 3 of the NRA Act. Let us note that in the case of a customs and tax inspection within the scope of the tax law, the authority prepares not a report, but a result of the inspection. This difference is important because, pursuant to Article 82 section 3 of the NRA Act, the controlled party can correct a previously submitted tax return declaration in 14 days from the date of the delivery of the result of the inspection, and avoid - if the authority allows the correction - a customs proceeding.

Therefore, one should opt for the view that although the tax on goods and services and the excise tax in import are not customs duties, the rules of the customs and tax inspection discussed in Article 54 section 1 point 2 of the NRA Act should, however, be used for them, that is, the rules typical of the control of compliance with the provisions of the customs law. This is also supported by - and it was noted in writings - the principle of the fact of tax regulations becoming more and more similar to the provisions of the customs law in the case of the joint use of the customs and tax legislation (see i.a. Article 147a of the T.O.A.; Article 34 section 2 of the VAT Act; Article 28 section 1 of the A.E.T. $)^{32}$. The postulate of conducting proceedings in an effective way and without excessive duration is still also important. This may be ensured by the authority that accepted the customs application.

The declaration of the amount due of the fuel duty in the case of import is slightly different. It is not declared in a customs declaration, but in the information regarding the fuel duty, submitted according to the template specified in the Regulation of the Minister of Finance ${ }^{33}$ in time specified for customs duties to the head of the competent tax and customs office for the place of incurring the customs debt. In the case of revealing an irregularity in the declaration of the amount of the fuel duty on import, the said head of the tax and customs office will be obligated to initiate proceedings in the matter and determine the correct amount of the fuel

\footnotetext{
32 See K. Lasiński-Sulecki, Umowy w sprawie unikania podwójnego opodatkowania a prawo celne. Wybrane zagadnienia In: Regulacje w zakresie prawa celnego i podatku akcyzowego po przystapieniu Polski do Unii Europejskiej. Doświadczenia i perspektywy, eds. P. Stanisławiszyn, T. Nowak, Warsaw 2012, pp. 295-296.

33 See Regulation of the Minister of Finance of 16 August 2017 on determining the template of information concerning the fuel duty (Dz. U. Poz. 1671/Journal of Laws, item 1671).
} 
duty in connection with the import of goods. Therefore, similarly as in the case of taxes on import, a customs and tax inspection concerning the fuel duty should be conducted on terms appropriate for a customs and tax inspection concerning compliance with the provisions of the customs law. It may be added that proceedings regarding the determining the correct amount of the fuel duty on import will be conducted on the basis of the provisions of the Tax Ordinance Act, including the changes resulting from the Act on Toll Motorways and the National Road Fund because the provisions of the Tax Ordinance Act are applied to the fuel duty, respectively ${ }^{34}$.

The experience of the Tax and Customs Service and earlier of the Customs Service should also be used to strengthen the manner of controlling the import excise goods from third party countries, where such goods are not excised, to the Republic of Poland. This would decrease the risk of importing them to the European Union by units which function on the grey market. They make use of the lack of the full harmonisation in terms of the excise tax in the countries of the European Union $^{35}$. Concurrently, an increase in controls of import to Poland and of trade in used and waste oils should be considered. The import of the oils limits the level of the consumption of legal heating oils and contributes to the pollution of the natural environment. It is also a direct violation of the Polish excise legislation ${ }^{36}$. The legislation work in the European Union which concerns updating the Waste Framework Directive is moving towards trade in waste oils in the framework of a closed economy, which requires a significant increase in the level of the collection of oils, the obligation to recycle waste oils, as well as customs and tax inspection that would monitor and check the physical movement of loads both through the external borders of the European Union and cross-border movement between the member states of the $\mathrm{EU}^{37}$. The proactive actions of the NRA should cover the predictive monitoring of trade offers on online platforms in this respect before the waste and

34 Article 37q of the Act of 27 October 1994 on Toll Motorways and the National Road Fund.

35 In Poland, mineral oils (CN 2710) were excised with a rate of PLN 1180 per 1000 litres, and synthetic greasing oils were not (CN3403). A new rate of the excise tax would be calculated as a weighed average, so that the total excise tax on both types of imported greasing oils would remain unchanged. Polska Organizacja Przemysłu i Handlu Naftowego (POPiHN), Raport roczny 2017, Przemyst i handel naftowy, Warsaw 2018, http://www.popihn.pl/raporty2.php, p. 9 (16 October 2018).

36 Polska Organizacja Przemysłu i Handlu Naftowego (POPiHN), op. cit., p. 9.

37 The necessity and ways of recycling waste oils and of transporting them were specified in Directive 2008/98/EC of the European Parliament and of the Council of 19 November 2008 on waste and repealing certain Directives, https://eur-lex.europa.eu/legal-content/pl/TXT/?uri=CELEX:32008L0098 (18 October 2018). 
used oils are moved; these actions should additionally cover the movement of oils in the EMCS (Excise Movement and Control System) in the whole European Union ${ }^{38}$.

\section{Conclusions}

The reform of the NRA implemented in 2017 is the first step towards increasing the state control over the collection of customs duties and other fees related to the import of goods from outside the EU. As a result of establishing the energy and fuel package in 2017 as well as the improvement of the functioning of the NRA, the official import of liquid fuels in 2017 increased by 2.2 million $\mathrm{m}^{3}$, that is, by $24 \%$ in relation to $2016^{39}$. A serious threat to the functioning of the NRA is a delay concerning the implementation of the new standards of customs and tax inspection by introducing the obligation of the proactive and predictive monitoring of import offers in the area of sensitive goods which could be the subjects of illegal import onto the territory of the EU, excluding the quantitative quotas not only in terms of the liquid fuels (the import of goods outside the official EU quota), the excise fee, fuel duty or VAT.

A postulate de lege ferenda would be an amendment of the NRA Act, clearly indicating that a customs and tax inspection regarding taxes (including the fuel duty) in import ends - as in the case of an inspection concerning compliance with the provisions of the customs law - with a report. It would then be undeniable that a potential tax proceeding regarding the import tax should be conducted by the authority that accepted the customs application. The increase in the NRA's effectiveness should be multidimensional and should be implemented with the effective use of the law in mind. Not only should the scope of the grey market be limited, and the conditions of the fair market play of legally registered economic entities strengthened, but also the situation of the State Treasury's own income should be improved systematically.

\section{References}

Lasiński-Sulecki K., Opłata paliwowa - próba oceny zgodności z prawem Unii Europejskiej, w: Prawo celne i podatek akcyzowy. Kierunki przeobrażeń i zmian, red. P. Stanisławiszyn, T. Nowak, Warszawa 2014.

38 Polska Organizacja Przemysłu i Handlu Naftowego (POPiHN), op. cit., p. 9.

39 Ibidem. 
Lasiński-Sulecki K., Umowy w sprawie unikania podwójnego opodatkowania a prawo celne. Wybrane zagadnienia, w: Regulacje w zakresie prawa celnego i podatku akcyzowego po przystąieniu Polski do Unii Europejskiej. Doświadczenia i perspektywy, red. P. Stanisławiszyn, T. Nowak, Warszawa 2012.

Melezini A., w: Krajowa Administracja Skarbowa. Komentarz, red. A. Melezini, K. Teszner, Wolters Kluwer, Warszawa 2018.

Nadolska A., Administracja skarbowa, w: Podstawy prawa finansowego, red. A. Drwiłło, Wolters Kluwer, Warszawa 2018.

Nowak T., w: Krajowa Administracja Skarbowa. Komentarz, red. A. Melezini, K. Teszner, Wolters Kluwer, Warszawa 2018.

Piech K., Procedura tranzytu jako pierwowzór procedury zawieszenia poboru akcyzy. O zwiąkach prawa akcyzowego z prawem celnym na podstawie doświadczeń niektórych państw członkowskich Unii Europejskiej, w: Prawo celne i podatek akcyzowy. Kierunki przeobrażeń i zmian, red. P. Stanisławiszyn, T. Nowak, Warszawa 2014.

Polska Organizacja Przemysłu i Handlu Naftowego (POPiHN), Raport roczny 2017, Przemyst $i$ handel naftowy, Warszawa 2018, http://www.popihn.pl/raporty2.php (dostęp: 16.10.2018).

PwC, Walka z szarą strefą. Wptyw regulacji na branżę paliw ptynnych, http://ungc.org.pl/ strefa-wiedzy/22202/

Reiwer-Kaliszewska A., Nowak T., Właściwość organów Krajowej Administracji Skarbowej w postępowaniu z tytułu importu towarów oraz w sprawach optaty paliwowej, w: Prawo celne, podatek akcyzowy oraz kary pieniężne w ustawie o grach hazardowych. Doświadczenia i wyzwania, red. T. Nowak, P. Stanisławiszyn, Szczecin 2018

Sobczyk I., Ochrona i bezpieczeństwo obszaru celnego Wspólnoty Europejskiej w zadaniach $i$ kompetencjach Stużby Celnej, w: Bezpieczeństwo w administracji i biznesie we współczesnym świecie, red. M. Chrabkowski, C. Tatarczuk, J. Tomaszewski, Wyższa Szkoła Administracji i Biznesu im. Eugeniusza Kwiatkowskiego w Gdyni, Gdynia 2011. 